\title{
PROBING COMPREHENSION OF WH QUESTIONS IN AN ECHOLALIC CHILD
}

\author{
JOHN M. PANAGOS, Ph.D. (OHIO) \\ Dept. Speech Pathology and Audiology, Kent State University, Kent, Ohio.
}

\begin{abstract}
SUMMARY
Comprehension of What, Where and When Wh questions was evaluated in a four-and-one-half year old echolalic boy who displayed in therapy and at home equivocal response to various question forms. Deficits of comprehension were traced to an inadequately developed deep structure (particularly adverbials) rather than to limited knowledge of $W h$ transformations. Delayed development of semantic rules, as in the case of time distinctions, may block acquisition of those syntactic rules dependent upon them.
\end{abstract}

\section{OPSOMMING}

Begrip van Wat, Waar en Wanneer is by 'n $4 \frac{1}{2}$-jarige eggolaliese seuntjie geevalueer wat tuis en tydens terapie woordelikse nabootsing van vraagvorme gebruik het.

'n Gebrek aan begrip ontspring waarskynlik nie soseer uit 'n beperkte kennis van vraagtransformasies nie, as uit 'n dieptestruktuur wat nie toereikend ontwikkel het nie (veral met betrekking tot bywoorde).

Die aanleer van sintaktiese reëls wat van die semantiese ontwikkeling afhanklik is, kan verhinder word deur 'n vertraagde ontwikkeling van semantiese reëls (soos in die geval van onderskeiding van werkwoordtye).

In the course of evaluating comprehension of $W h$ questions in an echolalic boy named Evan we made some interesting clinical observations. When Evan first enrolled in our child language program at Kent State University at age four years he was hyperactive, inattentive and language delayed. Sentences and phrases spoken to him were typically repeated verbatim. A clinician would ask him, "What are these?" and Evan would reply with clear pronunciation, "What are these?" Spontaneous utterances were fragmented and telegraphic. They suggested a pre-base level of oral syntax development. ${ }^{7}$ There were also signs of delayed motor development. Toilet training had been later than might be expected, preference was shown for the left hand, vocal quality was husky and low-pitched, and gait was at times noticeably irregular. Otherwise Evan was regarded by all who knew him as a bright and healthy child with normal developmental potential. In addition he had the benefit of warm and caring parents, both with college degrees and considerable understanding of child development. The mother was a teacher of the deaf. 
After seven months of group and individual language therapy, focusing on expansion of the base grammar and particularly the auxiliary system within it, Evan had made considerable progress with us. At 4,8 his spontaneous sentences showed a good variety of expanded base strings with several properly applied elementary transformations. Here is a sample of Evan's sentences drawn from a corpus of spontaneous utterances collected at home and in free play sessions at the clinic ${ }^{5}$ :

(1) I already ask Jon.

(2) We're having those cookies up there.

(3) I want to use blue on my caterpillar.

(4) Albert doesn't talk (elephant puppet).

(5) Move your chair, I can't.

(6) He waiting for me, for Evan.

(7) There are legs.

(8) The head is upside down.

(9) Want to play with us?

(10) Is Tarah coming?

(11) Was that John Panagos?

(12) What did you study?

(13) What's on top of that house?

(14) What you making?

(15) What's that under there?

(16) What did you at school, Trina?

(17) Hey you guys, what you doing here?

(18) What happen to Theresa's nose?

(19) Where's this go?

(20) Where's her flu?

(21) Where's a telephone pole?

(22) Where's Mother Goose (a book)?

(23) Where's Shurdon's blue dune buggy?

(24) Where Jeff get those cookies?

(25) My mom bought this shirt where?

(26) Who brought those?

(27) Who drew on the wall?

(28) Who draw that?

(29) Whose draw that truck?

(30) Whose papers are these?

Furthermore, hyperactivity had diminished along with the echolalic behavior. Evan could now sit at a table with his clinician for 40 minutes or more, and work through his lessons attentively without simply repeating everything said to him.

Comprehension of $W h$ questions, however, remained a problem. Depending on the type of interrogative involved (What, How, Why ...), responses were either inconsistently correct, or occurred not at all. Occasionally a given question (e.g. "What are you doing?") would cause Evan to revert to echolalia. Although, as mentioned, spoken sentences were now meaningful and syntactically well-formed, inconsistency in answering questions puzzled and 
frustrated Evan's parents, and presented a challenge to the clinician on the case. Apparently the problem we faced is not an uncommon one in clinical circles. Echolic children are found to be particularly sensitive to various question types ${ }^{4}$ as are younger normal children around the age of three years. $^{2}$

We thought it was time to probe Evan's comprehension of Wh questions more carefully. Why and How interroga tives were ruled out from the beginning for the reasons that they were structurally and semantically complex, and that

Evan to the best of our knowledge had never responded to them or used them in spontaneous speech. However, there was some evidence from speech samples that he could process What and Where questions. Although little was known about the When question, it was also of interest to us. The probe was begun with the What question because it seemed to be the most fundamental of the three. With the help of Evan's clinician, the evaluation was carried out over a three week period during individual therapy sessions.

\section{THE PROBE}

At the outset certain operating assumptions (ignoring some detail) were made about the What question. First, an intact noun phrase (NP) in the base is required for the application of the rule. Second, an $N P$ can be marked as either Human (someone) or Nonhuman (something). Third, the What morpheme is a kind of synonym for NP.Nonhuman. Fourth, What can replace NP-Nonhuman in an underlying string. Finally, when $N P$ substitution occurs in the predicate, the What morpheme is positioned at the beginning of the sentence. Assuming the application of auxiliary transposition and do support transformations, the steps from underlying to surface structure can be shown this way: John kicked the ball. $\rightarrow$ John kicked NP-Nonhuman (something) $\rightarrow$ John kicked what? $\rightarrow$ What did John kick? A similar analysis can be given for the Who question which differs from the What form only in that it applies to $N P$ Human rather than to NP-Nonhuman. Furthermore, the transformational principles of the What question are the same for all $W h$ questions in English, hence the much advertised power and generality of transformational rules. ${ }^{2}$

With the foregoing structural analysis in mind it was hypothesized that failure to comprehend the What question could be caused by: (1) absence of an intact or lexically differentiated underlying $N P$. (2) failure to distinguish $N P$. Human (someone) from NP-Nonhuman (something), (3) failure to associate What with NP-Nonhuman, (4) failure to grasp the What for NP substitution, or (5) failure to track the relocation of the What morpheme when moved from the predicate to the beginning of the sentence. To probe these components of comprehension of the What question was the task at hand.

It was found that Evan could comprehend all aspects of the What question. His clinician placed a group of small objects (car, ball, comb, penny ...), on the table in front of him and asked him to name each one in turn. He could do so without difficulty. Next the clinician asked, "What?", and simultaneously pointed to one of the objects. Accordingly, Evan named all of the items flawlessly. Then the clinician pointed again to the objects, one at a time, and said, "This is what?", making the What substitution in the predicate. Still 
Evan's naming responses were correct and unhesitating. Finally, the inverted form of the What question was asked, "What is this?", and the same pattern of correct response obtained. Thus knowledge of the What question within the limits of the tasks used was assumed. Evan's parents agreed. They reported his ability to name was exceptional, and that he always answered what questions as well as Who questions whenever they were asked of him. Inspection of our corpus of spontaneous utterances revealed a number of well-formed What questions involving both subject and predicate contexts ( $c f$. sentences 12-18 above). Who questions (sentences 26-28) were also present.

Next a similar analysis of the Where question was performed. The Where question relies on the same transformational principles used in the What question, except that the phrase structure context of the replacement process is the place adverbial (somewhere) instead of the noun phrase. From deep to surface structure, then, the progression takes this form: The ball is there (somewhere) $\rightarrow$ The ball is where? $\rightarrow$ Where is the ball? A variant form is one in which the place adverbial is a prepositional phrase: The ball is in the box (somewhere) $\rightarrow$ The box is where? $\rightarrow$ Where is the ball? In this case the Where morpheme replaces an entire phrase with its own internal structure (Prep + $N P$ ). Furthermore, the relations between the prepositions and noun phrases designate spatial relations within the conceptual system.

The objects used to evalua te comprehension of the What question were used to evaluate the Where question. They were divided into two groups and separated spatially. Half were placed on the therapy table at which Evan was seated, and the other half were positioned on a second table across the room. In a sense Evan was asked to name the location of the objects with the adverbials here and there. Upon hearing the word "ball", for example, he was required to say "there" because it was located on the distant table. Evan could perform this locative task easily, making no errors in the process. The same held true for the sentence forms, "The ball is where?" and "Where is the ball?" He responded quickly and accurately to all questions asked. The results here were consonant with those found for the What question. In both cases Evan showed the ability to process separately and collectively all phases of $W h$ question derivation.

However, when the testing paradigm required a response with a locative prepositional phrase, the picture changed somewhat. Ability to respond correctly depended directly on knowledge of prepositions. With all of the objects placed on the table in front of Evan, along with a cardboard box, the clinician selected an object and held or placed it in a position relative to the box. Asked "Where is the ball?", Evan could reply appropriately with "on the box"'and "in the box", but not with "behind the box" or "near the box". Many prepositions like near, behind, and between, as well as the phrases in front of, and close to, were simply unknown to Evan, and this was the reason why some Where questions were incomprehensible to him. ;

Examination of the corpus of spontaneous utterances showed a good number of well-formed Where questions (cf. sentences 19!25 above) to support the findings of our comprehension testing. There was', interestingly enough, one sentence in which When replacement occurred in the predicate without pre- 
posing (My mom bought this shirt where?). The base included a sufficient number of place adverbials to define the category, but lexical differentiation was limited. Prepositional phrases included only six locative Prep $+N P$ sequences (at-, from-, to-, on-, in-, under-).

The When interrogative next evaluated is structurally similar to the What and Where questions, except that it elicits from the base information concerning time adverbials. Time adverbials can be single words (now, later, today) or phrases (in the evening, last night, in June). Transformationally we have, I ate the cake yesterday (sometime) $\rightarrow$ I ate the cake when? $\rightarrow$ When did I eat the cake? Adverbials of time of course do not make reference to tangible objects, but to abstractions about the time continuum (Weber and Weber, 1973). This fact makes When questions difficult to evaluate, since, unlike What and Where forms, objects cannot be displayed as the context of testing. Our only alternative was to query Evan about obvious time distinctions (yesterday-today, last-night, this-morning. . .) perhaps known to him from everyday experience. Our efforts to probe the When question were short lived. Questions like, "When did you watch hockey, Evan?", or, "You ate dinner when?" went unheeded. Evan would just mumble to himself and look down at the therapy table in front of him. His mother confirmed our observations: "Time concepts are really a problem for him. He doesn't seem to remember when he's . done something" (like going to his grandfather's). Review of the corpus items quickly revealed the problem. It was that Evan did not have a sufficiently developed system of time adverbials with which to understand When questions. There were only two occurrences of time adverbials, both single words and quite likely memorized items (No, I already did (write to Santa). He still lives in Mansfield?). Nor could there be found a single When question. In fact, there was in general little evidence of grammatical productivity of time features. A few strong verbs of past-tense form were located (Who drew on the wall? Who was that on the phone? My mom bought this shirt where?), as well as one instance of an inflected verb (I burped). In several instances do carried past-tense meaning appropriately (What did you study? What did you at school? . . .). However, many of these utterances had an immediacy to them (I burped now) or reflected only the grossest differentiation of time categorization. Temporal adverbials serving as sentence conjunctions (before $S$, when $S$ ) were totally absent from the corpus. All available evidence indicated that Evan possessed a highly restricted system of temporal concepts whose contributions to syntactic development were minimal.

\section{DISCUSSION}

The findings of our inquiry into Evan's comprehension of Wh questions can be summarized as follows. Adult native speakers around him (parents, clinicians) indicated difficulty in understanding Wh questions, but for the most part this judgment proved erroneous. Evan had receptive and expressive control over the operations of the $W h /$ constituent association, $W h$ for constituent replacement, and $W h$ preposing, both as separate steps in the derivation of interrogatives, and combined processes. ${ }^{2}$ Rather what determined and predicted his comprehension performance was the availability or nonavailability of underlying phrasal categories to which particular Wh questions referred. 
Noun phrases were well developed lexically and therefore What questions presented no difficulty. Adverbials of place were reasonably established in the base, so Where questions were not problematic, unless specific prepositions mapping spatial relations were involved. Finally, When questions could not be answered, for they were referenced to nonexistent time adverbials or temporal concepts. In short, Evan's comprehension difficulty lay less with comprehending questions than it did in understanding particular aspects of the deep structure of the language.

In 1965 Chomsky $^{3}$ revised his theory of generative grammar to include a semantic component having the purpose of interpreting the meaning of syntactic strings. Then and since then, there has been considerable debate about the nature and scope of the semantic component and its influence on syntactic rules. That the two components have reciprocal influences on one another in early language acquisition was insightfully demonstrated by Bloom ${ }^{1}$ and further clarified by MacNamara. ${ }^{6}$ Some recent evidence dealing with the acquisition of time designations demonstrates the independence and uniqueness of semantic systems. ${ }^{8}$ These advances in semantic theory are applicable here. Our hyperactive and echolalic friend Evan, with his perceptual inclination to be bound to the here-and-now, seemed to lack adequate semantic acquisition to support aspects of his syntax development. Most striking was his inadequate knowledge of temporal concepts relating to time adverbials in the base of his syntax grammar. It could be hypothesized that the absence of a semantic system of time concepts was blocking grow th at several levels of syntactic development. With Figure 1 the ways in which this influence might

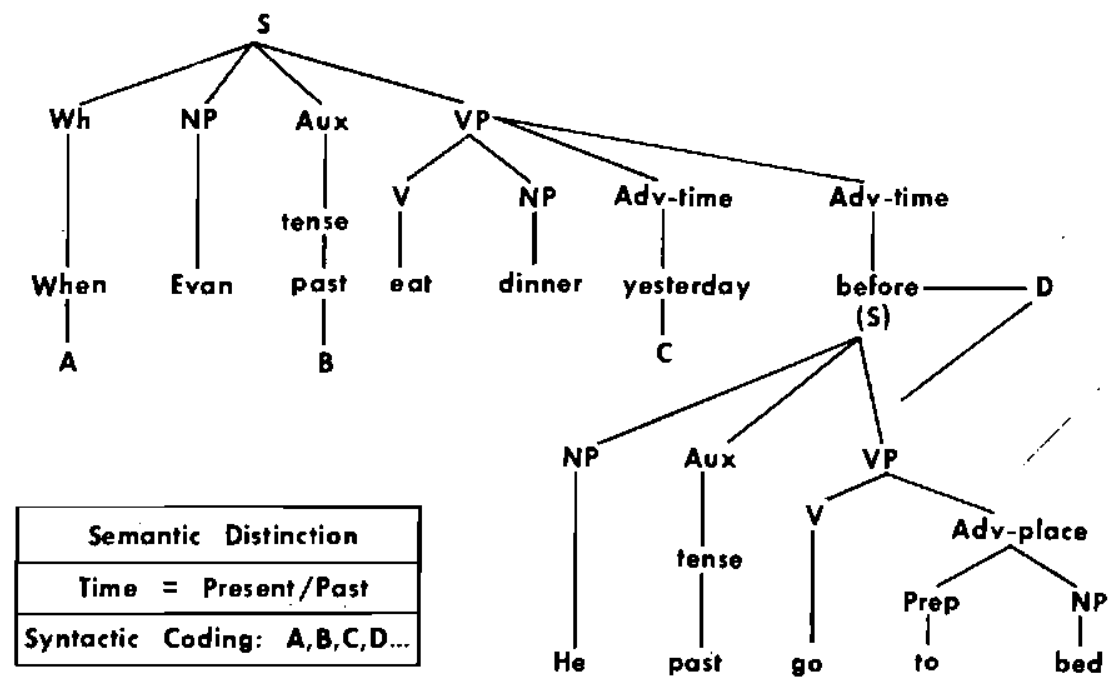

Figure 1. Hypothetical phrase marker representation showing various syntactic contexts $(A-D)$ in which the present/past semantic distinction is coded. 
be manifested are illustrated. It can be seen that the nonacquisition of the semantic distinction of present/past could simultaneously affect development of the When question $(A)$, tense marking of the main verb $(B)$, time adverbials within the base $(C)$, and embedded strings derived from time adverbials $(D)$. We have therefore a semantic deficit affecting the distinctly different syntactic processes of morpheme inflection, phrase structure categorization. simple transformations, and generalized transformations. Certainly semantic rules about which little is known can have subtle and far-reaching effects on the syntax development of normal children, and on language-impaired children like Evan.

\section{ACKNOWLEDGMENTS}

My thanks to Roberta Bronahan, Sheila Higgins, Judy Badovinac, Sue Williams, and Patricia Dukes for sharing sentence data with me, and to Candice Wice who was the clinician on the case and helped with the evaluation reported here. Special thanks go to my friends Tom and Jane, Evan's parents, and to Evan himself, who continues to be a delightful fellow to know.

\section{REFERENCES}

1. BLOOM, L. (1970): Language Development. Cambridge, Mass.: M.I.T. Press.

2. BROWN, R. (1968): The development of Wh questions in child speech. $J$. Verb. Learn. Verb. Behav., 7, 279-290.

3. CHOMSKY, N. (1965): A spects of the Theory of Syntax. Cambridge, Mass.: M.I.T. Press.

4. FAY, W.H. (1973): Occurrence of children's echoic responses according to interlocutory question types. Unpublished manuscript, University of Oregon Medical School.

5.. HIGGINS, S.M. (1973): Normal and disordered child language: grammatical analysis and comparison. Unpublished seminar paper, Kent State University.

6. MACNAMARA, J. (1972): Cognitive basis of language learning in infants. Psychol. Rev., 79, 1-13.

7. MENYUK, P. (1969): Sentences Children Use. Cambridge, Mass.: M.I.T. Press.

8. WEBER, J., and WEBER, S. (1973): Early acquisition of linguistic designations for time. Unpublished paper delivered at American Speech and Hearing Association Convention, Detroit, Michigan. 




